Bożena Tuszewska, Wprowadzenie do pracy nad tekstem historycznym i liturgicznym (chronologia, jednostki mierzenia czasu, kalendarz, systemy datowania), [w:] Starożytność chrześcijańska. Materiały zebrane, red. Józef Cezary Kałużny, t. 4, Kraków 2016, s. 233-241. DOI: http://dx.doi.org/10.15633/9788374385282.14

Bożena Tuszewska

UNIWERSYTET PAPIESKI JANA PAWŁA II W KRAKOWIE

\title{
Wprowadzenie do pracy nad tekstem historycznym i liturgicznym (chronologia, jednostki mierzenia czasu, kalendarz, systemy datowania)
}

Niniejszy tekst poświęcony został zagadnieniu wprowadzania w trakcie kursu języka łacińskiego informacji na temat chronologii, jednostek mierzenia czasu, kalendarzy oraz systemu datowania. Poniżej zamieszczono szereg autorskich scenariuszy zadań, które pozwalają na połączenie filologicznej pracy nad tekstem oraz doskonalenie konkretnych umiejętności językowych z poszerzeniem wiedzy studentów o informacje z zakresu chronologii historycznej. Przy czym ćwiczenia zaczerpnięte zostały z materiałów opracowanych na potrzeby kursów, jakie realizowane są na Uniwersytecie Papieskim Jana Pawła II w Krakowie dla studentów teologii kapłańskiej oraz historii Kościoła i archiwistyki.

Problematyka ta stanowi rozwinięcie tematu gramatycznego Numeralia cardinalia et ordinalia - liczebniki główne i porządkowe, realizowanego w trzecim semestrze wyżej wzmiankowanych kursów. Poprzedzona jest także wprowadzeniem konstrukcji ablativus temporis, odpowiadającej na pytania „kiedy?”, „w jakim przeciągu czasu?”, np. horis duabus, diebus quattuor, Filius hominis in corde terrae tribus diebus noctibusque erit ${ }^{1}$. Po takim wprowadzeniu gramatycznym możliwe jest poszerzenie wiedzy studentów o konkretne informacje z zakresu chronologii historycznej.

I tak, dla pełnego rozumienia tekstów łacińskich niezbędne jest wprowadzenie antycznych i chrześcijańskich nazw dni tygodnia, które to nazwy

1 Zob. Z. Samolewicz, T. Sołtysik, Składnia łacińska, Bydgoszcz 20oo, s. 81-82. 
można porównać z innymi językami nowożytnymi (włoskim, hiszpańskim, francuskim, angielskim, niemieckim) oraz wyjaśnić ich pochodzenie od imion bóstw.

\section{Nomina dierum}

Nazwy antyczne i chrześcijańskie niedziela - dies Solis Dominica poniedziałek - dies Lunae feria secunda wtorek - dies Martis feria tertia środa - dies Mercurii feria quarta czwartek - dies Iovis feria quinta piątek - dies Veneris feria sexta sobota - dies Saturni Sabbatum

Znajomość nazw dni tygodnia można wyćwiczyć na przykład poprzez tłumaczenie i modyfikowanie poniższych zdań:

Hodie dies Iovis est. Cras.... Heri....

Qui dies tibi dilectus est? Mihi placet..., (quod...)

Qui dies amico tuo (amicae tuae) dilectus est?

Kolejnym zagadnieniem jest omówienie łacińskich nazw miesięcy - podobnie jak powyżej - połączone z wyjaśnieniem ich pochodzenia oraz porównaniem brzmienia $\mathrm{z}$ formami obecnymi w językach nowożytnych. Warto na tym miejscu zwrócić uwagę studentów na niezgodność liczebnikowych nazw miesięcy z kolejnością ich występowania. Wiąże się to $\mathrm{z}$ faktem, iż pierwotnie rok dzielił się na dziesięć miesięcy, z których pierwszym był marzec. W 150 roku a.Ch.n. dodano Februarius, a następnie Ianuarius i za moment rozpoczęcia roku uznano dzień 1 stycznia².

\section{Nomina mensium}

styczeń - mensis Ianuarius

luty - mensis Februarius

${ }^{2}$ Zob. O. Jurewicz, L. Winniczuk, Starożytni Grecy i Rzymianie w życiu prywatnym i państwowym, Warszawa 1968, s. 239. 


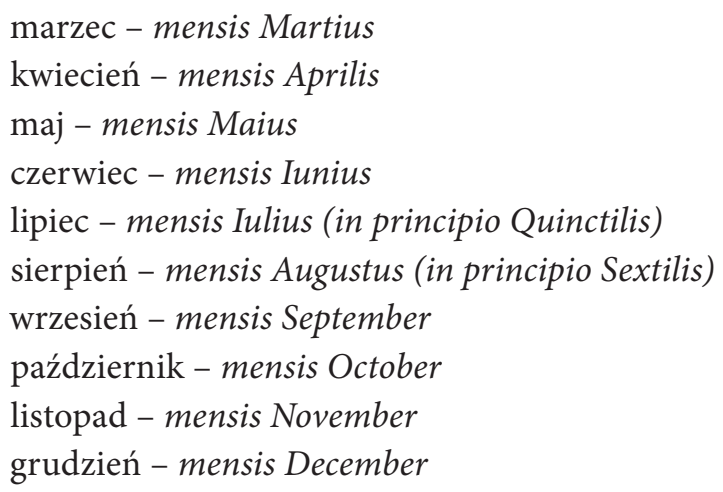

Naukę nazw miesięcy można wesprzeć, ćwicząc udzielanie odpowiedzi na poniższe pytanie:

Qui mensis tibi dilectus est? Mihi placet mensis..., (quod...).

Rzeczą konieczną jest również wprowadzenie studentów - poprzez prezentację lub wykład - w problematykę sposobów datowania, jakie można napotkać w łacińskich tekstach starożytnych czy średniowiecznych.

Wyjaśnienia będzie więc wymagało określanie daty rocznej:

- według urzędujących konsulów, np. Gn. Pompeio et M. Crasso consulibus,

- od objęcia rządów przez poszczególnych władców,

- poprzez wprowadzenie stałej daty początkowej: ab Urbe condita (753 p.n.e.) $)^{3}$, rzadziej początek republiki po wypędzeniu ostatniego króla post reges exactos (510 p.n.e.), od początku jakiejś wojny, np. quarto decimo anno belli Punici,

- od narodzenia Chrystusa - post Christum natum, incarnationis Domini, anno Domini ${ }^{4}$.

Poruszyć należy także kwestię kalendarza, uwzględniając następujące zagadnienia:

3 Przy czym pamiętać należy, iż 753 rok p.n.e. to rok pierwszy, a nie zerowy. Zatem rok konsulatu Cycerona to rok 63 p.n.e. lub 691 a.U.c. $(754-63)$.

4 System ten wprowadził Dionizjusz w 556 roku. Z czasem zaczęto liczyć także lata przed narodzeniem Chrystusa - ante Christum natum. Zob. O. Jurewicz, L. Winniczuk, Starożytni Grecy i Rzymianie..., dz. cyt., s. 236-237; J. Naumowicz, Geneza chrześcijańskiej rachuby lat. Historyczno-teologiczne podstawy systemu Dionizego Mniejszego, Tyniec 2000. 
- rok księżycowy, obowiązujący w Rzymie do 46 a.Ch.n. i liczący 365 dni (dla wyrównania z porami roku dodawano mensis intercalaris),

- rok słoneczny, wprowadzony przez Cezara od 1 stycznia 45 a.Ch.n. i liczący 365 dni, a co cztery lata - 366 dni (rok przestępny),

- kalendarz gregoriański, wprowadzony w 1582 roku na mocy bulli papieża Grzegorza Xıı i niwelujący nieścisłości kalendarza juliańskiego5.

Powyższe informacje na temat chronologii wymagają jeszcze uzupełnienia o zagadnienie zapisu daty dziennej w łacinie antycznej i chrześcijańskiej. W pierwszym przypadku istniały stałe daty na oznaczenie dni miesiąca:

- Kalendae, -arum - 1. dzień miesiąca,

- Nonae, -arum - 5 lub 7 dzień miesiąca (9 dzień przed idami),

- Idus, -uum - 13 lub 15 dzień miesiąca (15 w marcu, maju, lipcu i październiku) $)^{6}$.

W zdaniach określenie czasu za pomocą tych nazw wymagało zastosowania ablatiwu, np. Idibus Martiis.

Stosowano także określenia:

- pridie - dzień przed (np. pridie Nonas Octobres, czyli 6 października),

- postridie - dzień po (np. postridie Kalendas Octobres, czyli 2 października),

- ante diem - przed dniem (np. ante diem quintum Nonas Octobres, czyli 3 października) 7 .

Z kolei łacina chrześcijańska używała kolejnych liczebników porządkowych w odpowiedzi na pytanie „kiedy?”, odmieniając je odpowiednio $\mathrm{w}$ genetiwie i ablatiwie, np. dies vicesima prima mensis Octobris $>$ die (abl.) vicesima prima mensis (gen.) Octobris anno (abl.) bis millesimo tertio decimo.

\footnotetext{
${ }^{5}$ Rok juliański jest o 11 minut i 14 sekund dłuższy od roku słonecznego, stąd co 128 lat powstaje różnica jednego dnia. Decyzją Grzegorza xıII opuszczono rozbieżność narosłą od czasów Cezara - po 4 października nastąpił 15 października. Wprowadzono także zasadę, według której końcowe lata stulecia mogą być przestępnymi, jeśli dwie pierwsze cyfry tworzą liczbę podzielną przez 4. Rok gregoriański jest dłuższy od roku zwrotnikowego o 26 sekund, jednak różnica jednego dnia nastąpi dopiero po 3300 latach. Zob. J. Wikarjak, Gramatyka opisowa języka łacińskiego, Warszawa 1997, s. 156-157.

${ }^{6}$ Zob. Vademecum historyka starożytnej Grecji i Rzymu, t. 1, red. E. Wipszycka, Warszawa 2001, s. 551; t. 3, red. E. Wipszycka, Warszawa 1999, s. 358.

7 Zob. Chronologia polska, red. B. Włodarski, Warszawa 1957, s. 30; J. Wikarjak, Gramaty$k a \ldots$, dz. cyt., s. $158-159$.
} 
Naukę datowania wyćwiczyć można przez poniższe zadania ogólne oraz uwzględniające specyfikę kierunków studiów teologicznych i historycznych:

Ćw. 1. Powiedz w inny sposób po łacinie: Idibus Februariis, ante diem tertium Kalendas Decembres, pridie Nonas Septembres, dies quinta mensis Iunii... Ćw. 2. Podane daty zapisz słownie i cyframi rzymskimi: w roku 1683, w roku 1918, w roku 1410, w roku 966, w roku $1978 \ldots$

Ćw. 3. Przetłumacz na j. łaciński: 3 maja 1791 roku, 1 września 1939 roku, 24 grudnia 2013 roku, 6 stycznia 2000 roku...

Dla studentów kierunku historia Kościoła i archiwistyka:

Odpowiedz na następujące pytania: Quo anno Mescho, rex Poloniae baptizatur? Quo anno Boleslaus, rex Poloniae episcopum Stanislaum occidit? Quo anno Hedvigis in regem Poloniae coronatur? Qua die Urbs Roma condita est?

Dla studentów kierunku teologia kapłańska:

Uzupełnij daty, sięgając do kalendarza.

Anno (2013)... festa mobilia Ecclesiae catolicae celebrantur: Dominica Septuagesima..., Feria Quarta Cinerum..., Dominica Resurrectionis..., Ascensio Domini..., Dominica Pentecostes..., Festum Ssmi Corporis Christi..., Dominica I Adventus....

Ponieważ zaś fructus scientiae dulcis est, zatem po powyższych wyjaśnieniach można przystąpić do tłumaczenia tekstów, w których pojawiają się zagadnienia chronologiczne, np.:

Dla studentów obydwu wymienianych kierunków:

Tres dies et noctes sunt in quibus si vir natus fuerit, corpus eius sine dubio integrum manet usque in diem iudicii: hoc est in VI Kalend. Februarii, et III Kalend. et Idus Febr., et suum mysterium mirabile est valde.

Die Dominica hora diuturna, sive nocturna, qui natus fuerit, magnus erit et splendiosus.

Feria secunda, fortis erit.

Feria tertia, cupidus erit, et de ferro moritur.

Feria quarta, tractator regni erit. 
Feria quinta, affabilis erit et honorificus.

Feria sexta, rivalis erit et multum luxuriosus.

Sabbato, raro utilis erit ${ }^{8}$.

Historyków z pewnością zainteresuje poniższy fragment Rocznika (krakowskiego) dawnego:

DCCCCXVI Dubrouka venit ad Meskonem.

DCCCCXXXII Zlaunyk pater sancti Adalberti obiit.

DCCCCXXXVIII mater sancti Adalberti obiit.

DCCCCXCVIII passio sancti Adalberti.

MII Otto imperator III obiit. Henricus successit.

MXVIII Bolezlaus superavit Ruziam.

MXXV Bolezlaus Magnus obiit.

MLVIII Kazimyr dux obiit.

MLXXVII Bolezlaus II coronatus est.

MLXXXVI Bolezlaus III natus est.

MLXXXVIII Mysco duxit uxorem.

MLXXXVIIII Mysco obiit.

MXCI Wladizlaus dux Pomeranos ad Drecim.

мXCII Bogumylus archiecopus obiit.

Objaśnienia: Drecim - Drzycim, Zlaunyk - Sławnik

Natomiast klerykom zaproponować można wyjątki z Mszału rzymskiego ${ }^{10}$ :

I. De Triduo paschali

19. Triduum paschale Passionis et Resurrectionis Domini incipit a Missa vespertina in Cena Domini, habet suum centrum in Vigilia paschali, et clauditur Vesperis dominicae Resurrectionis.

20. Feria vi in Passione Domini,(9) et, iuxta opportunitatem, etiam Sabbato sancto usque ad Vigiliam paschalem,(10) ubique celebratur sacrum ieiunium paschale.

\footnotetext{
${ }^{8}$ Beda Venerabilis, De nativitate infantium libellus, [w:] Patrologiae cursus completus. Series latina, t. 94, ed. J. P. Migne, Parisiis 1862, kol. 959-960.

${ }^{9}$ Rocznik (krakowski) dawny, [w:] Monumenta Poloniae Historica, t. 5, ed. Z. Kozłowska-Budkowa, Warszawa 1978, s. 4-5.

${ }^{10}$ Missale Romanum. Normae universales de anno liturgico et de calendario, http://www. clerus.org/bibliaclerusonline/it/index2.htm (28.02.2014).
} 
21. Vigilia paschalis, nocte sancta qua Dominus resurrexit, habetur ut „mater omnium sanctarum Vigiliarum”,(11) in qua Ecclesia Christi resurrectionem vigilando exspectat, eamque in sacramentis celebrat. Ergo tota huius sacrae Vigiliae

IV. De tempore Nativitatis

32. Post annuam mysterii paschalis celebrationem, nihil antiquius habet Ecclesia quam memoriam Nativitatis Domini et primarum eius manifestationum recolere: quod fit tempore Nativitatis.

33. Tempus Nativitatis decurrit a I Vesperis Nativitatis Domini usque ad dominicam post Epiphaniam, seu post diem 6 ianuarii, inclusive.

34. Missa in Vigilia Nativitatis adhibetur vespere diei 24 decembris sive ante sive post I Vesperas. Die autem Nativitatis Domini, Missa ter celebrari potest, secundum antiquam traditionem romanam, scilicet in nocte, in aurora et in die.

35. Nativitas Domini suam habet octavam sic ordinatam:

a) dominica infra octavam, vel, ea deficiente, die 30 decembris, fit festum

S. Familiae Iesu, Mariae et Ioseph;

b) die 26 decembris, fit festum S. Stephani, Protomartyris;

c) die 27 decembris, fit festum S. Ioannis, Apostoli et Evangelistae;

d) die 28 decembris, fit festum Ss. Innocentium;

e) dies 29, 30, 31 sunt dies infra octavam;

f) die 1 ianuarii, in octava Nativitatis, fit sollemnitas Sanctae Dei Genetricis Mariae, in qua commemoratur etiam impositio Ss.mi Nominis Iesu.

36. Dominica a die 2 ad diem 5 ianuarii occurrens est Dominica II post Nativitatem.

37. Epiphania Domini celebratur die 6 ianuarii, nisi, ubi non est de praecepto servanda, assignata sit dominicae a die 2 ad diem 8 ianuarii occurrenti (cf. n. 7). Dominica post diem 6 ianuarii occurrente, fit festum Baptismatis Domini.

Do ćwiczenia znajomości łaciny oraz zasad określania datacji w tekstach starożytnych doskonale nadają się również inskrypcje ${ }^{11}$. Przy czym źródła takie zainteresują zarówno słuchaczy studiów historycznych, jak i teologicznych, np.:

${ }^{11}$ Wszystkie przytoczone poniżej inskrypcje pochodzą z: T. Lansford, The Latin inscriptions of Rome. A walking guide, Baltimore 2009. 
Watykan, Porta di S. Rosa, Dedykacja Benedykta XVI

BENEDICTVS XVI P M

CIVITATIS VATICANAE OFFICIALIUM COMMODITATI

OSTIVM

APERIRI IVSSIT

A D MMVI PONT I

Objaśnienia: $P$ (ontifex) $M$ (aximus), PONT(ificatus)

Bazylika św. Piotra, Dedykacje relikwiarzy:

św. Weronika

SALVATORIS IMAGINEM VERONICAE SVDARIO EXCEPTAM

VT LOCI MAIESTAS DECENTER CUSTODIRET

URBANVS VIII PONT MAX CONDITORIVM EXTRVXIT ET ORNAVIT

ANNO IVBILEI MDCXXV

SANCTA VERONICA IEROSOLYMITA

św. Helena

PATREM CRVCIS QVAM HELENA IMPERATRIX E CALVARIO IN VRBEM AVEXIT VRBANVS VIII PONT MAX E SESSORIANA BASILICA

DESVMPTAM

ADDITIS ARA ET STATVA

HIC IN VATICANO CONDITORIO COLLOCAVIT

SANCTA HELENA AVGVSTA

Lateran, Epitafium św. Marcina

MENS III DIES XII OBIIT AN

MCCCCXXXI DIES FEBRVARII

TEMPORVM SVORVM FILICITAS

Obelisk Flaminio (Plazza del Popolo) - dedykacja Augusta

IMP CAESAR DIVI $(f)$

AUGUSTUS

PONTIFEX MAXIMVS

IMP XII COS XI TRIB POT XIV

AEGVPTO IN POTESTATEM

POPULI ROMANI REDACT(a)

SOLI DONUM DEDIT 
Objaśnienia: IMP(erator), CO(n)S(ul), TRIB(unica), РОT(estate), XII -

duodecimum...

Piazza del Popolo, Porta del Popolo, Dedykacja S.P.Q.R.

ANNO MDCCCXXIX

RESTITVTAE LIBERTATIS $X$

TURRIBVS VTRINQUE DELETIS

FRONS PRODVCTA INSTAVRATA

$S P Q R$

VERBE ITALIAE VINDICATA

INCOLIS FELICITER AVCTIS

GEMINOS FORNICES CONDIDIT

Plac św. Marka, Epitafium Michała Anioła

MICHAEL ANGELUS

BONARROTIVS

SCULPTOR PICTOR ARCHITECTUS

MAXIMA ARTIFICUM FREQUENTIA

IN HAC BASILICA SS XII APOST FMC

XI KAL. MART A MDLXIV ELEVATVS EST

CLAM INDE FLORENTIAM TRANSLATVS

ET IN TEMPLO S CRVCIS EORVMD F

VID MART EIVSD A CONDITVS

TANTO NOMINI

NULLVM PAR ELOGIVM 